\title{
"The Influence of Systematic and Unsystematic Risk on the Development Strategy for Fashion Industry Subjects in the Emerging Markets"
}

\author{
Anna Khvorostyanaya \\ Lomonosov Moscow State University \\ Moscow, Russian Federation
}

\begin{abstract}
Annotation
In emerging markets, a crucial role is played by systematic and unsystematic risk management. This article analyses the impact of multifarious risks such as political and cultural on companies operations that deals in the fashion industry. Political risks and terrorism are exogenous risk-factors on which the company's strategist can hardly influence. However, a cultural risk-factor is amenable to management. Ignoring the last can reduce the investment effectiveness or even cause irreparable financial collapse.
\end{abstract}

\section{Introduction}

Over the past decade, many companies in the fashion industry attained exalted aims on their origin market reaching new heights in economic development while constructing high bandwidth retail network and building intense customer communication. Though once they had faced the stagnation trend caused by market oversaturation posing a serious challenge to the ability to undertake previous tasks and gain new goals. Purposely to preserve financial stability and amplify sales pace the new markets dilation could be the best way out. Cultural and creative industries $(\mathrm{CCI})$ help to drive the digital economy, form creative multi polar world, structure creative hubs, boost cities' attractiveness and bring forth talents. According to Ernst \& Young there are five global regions in CCI context (North America, Latin America and Caribbean, Europe, Asia-Pacific, Africa and the Middle East) that are definitely universal cornerstone of the global economy - For example, in 2013 they generated revenues of 2,25 billion USdollar and employed 29 million people [1]. Noteworthy, in this light, global CCIregions consist of wondrous emerging markets bringing an entire new way of thinking to the global fashion map. Government initiatives and support, an increased international brands conversance, higher consumer demand for fashion goods are the most appreciable industry growth drivers in the emerging fashion markets. In addition, over the last four years, the number of fashion events held in several emerging markets has more than doubled [2].Nevertheless emerging markets put company strategist into a flutter as opening broad prospective, there is also not a smaller risk to burn through and dramatically fail. Dealing with many uncertainties and unknown factors in emerging markets, successful strategists share a view of risk as a serious component of strategy. Traditionally, risk is typically divided into two main categories - systematic or country/region specific (risk that is usually considered to be non-probalistic, unpredictable, manageable) and unsystematic or company specific (risk that is probalistic, and therefore can be predicted, evaluated, managed strategically and operationally). It should be pointed out that according to the practice of foreign direct investment strategy, it is possible to conclude that systematic orcountry /region specific risk is predictable withal mostly unmanageable [3].The strategic political risk of investment is the exogenous factor focused on a country's political stability and the attitude of its political leadership toward domestic and foreign business. In the XXI century such factor of political riskas terrorism, became one of the main obstacles for direct foreign investments. To minimize political risks, company's strategists should be in a direct contact with leaders of the countries in which they plan to invest [4].The global market space created the strict need of foreign cultures understanding. Due to the application markets expansion strategy, to the forefront of global multinational companies which determine fashionable standards (LVMHMoët Hennessy - Louis Vuitton, INDITEX) appears a problem of the cultural environment features accounting in case of financial strategy development and implementation. In the fashion-strategizing process [5] as a separate industry direction of the financial strategizing, for the investments cultural risk minimization and increase in investment efficiency, the foreign companies need to take into consideration local traditions, historical features and mentality. 


\section{Political Risk as a Strategic Risk-Factor}

The prime minister of India Narendra Modi within fight against corruption, terrorism and «black money» (fake or unaccounted money), declared on November8, 2016 in televised address that 500 and 1000 rupees notes will stop being legal means of payment since November 9 (they can be exchanged for new banknotes inclusive till December 30) [6]. This statement wouldn't be rather shocking if it wouldn't be made less than in four hours till midnight. In an hour after the his statement, it was possible to note the sales demand increase - the flows of people directed in shops to spend the available cash before the notes validity period expires. The Prime Minister action is the kind of state regulation of the India shadow economy monetary sector. Suddenly, an exceptional short-term maximizing turnover opportunity appeared for retailers. Therefore, given the fact how vital it isto quickly analyze the external impulse in a fashion-strategizing process, manyretailers (including boutiques Bottega Veneta, Rolex, Dior, Gucci and other luxury stores) immediately changed their tactics by increasing working hours and also notifying buyers via WhatsApp and phone calls (that they work longer hours). WhatsApp is a free private commercial cross-platform messenger with support for voice that lets you to send text messages, images, video and audio via the Internet[7]. Nowadays, this mobile application is a resource - saving qualitative leap forward on informing customers. Due to the fact that retailer's track in advance of novelties in the Internet sphere technologies, they beforehand signed a contract on the messenger use in order to build their own effective CRM systems. In this case, after the Narendra Modi's speech, exclusively this has allowed them to promptly inform their clients about changes in their work schedule.

According to DarshanMehta, President and Chief Executive Officer of Reliance (operator and partner in India for international brands as Diesel, Ermenegildo Zegna, Steve Madden etc.) - «They did a terrific amount of sales during those three hours, which itself is not a normal situation...And then, of course, the next few days have seen a dramaticdip» [8]. The law enforcement services have not disregarded the fulminant consumer demand revival photo and video shooting were removed from some stores in Mumbai, including BottegaVeneta, and counterfeit banknotes were seized and transaction operations were verified. Thus, political risk was offset through change in daily tactics - leveled a potential decline in consumer demand caused by the banknotes withdrawal from circulation. This risk type was transformed into a significant financial profit by the rapid retailers reaction.

In the global emerging markets strategic management, terrorism is one of the most dangerous patterns in an open international arena of global market space [9].Terrorism can be attributed to the absolutely unpredictable and uninsurable risk type, and entrepreneurs virtually at any market (emerging or not) are vulnerable to such a severe threat. Leveling this type of political risk lies on the state, as on international co-operation organizations between countries against terrorism. However, not only in emerging markets there is a solemn need for risk foresight. The capital of France is recognized as a marvelous fashion industry center, and shows during Paris Fashion Week collect not only multi-million audience all around the world, but also impressively replenish the city's budget

(Paris Fashion Week seasons 2016-2017 brings 11,626,500 euro to Paris city's budget) [10].

After the cruel terrorist attacks series in November 13, 2015 in Paris, France travel industry has suffered (inbound flow reduction by 27\%) - this year the Parisian hotels and restaurants have lost nearly two million tourists [11]. The famous French LVMH group, the largest luxury goods manufacturer, in its financial statements noted a decrease in sales by $20 \%$ in the fourth quarter of 2015year in its Paris boutiques [12]. The fashion magazine TTT editor GaëlSavarysaid about dramatic changes during the first fashion week after the attacks - the fashion houses press services asked not to divulgate the presentation and runaway's places, and photographers were ordered to come to the fashion show with only the most necessary equipment [13]. However, the terrorism threat owing to spot the weak security measures have caused not only local changes - the procedure for event admission modified (increased security measures) - but also a distinguish change in consumer behavior. Now UK is seen by fashion goods consumers as a safer place to shop, despite the higher prices for the same goods brands (Louis Vuitton bag model SPEEDY 25 costs 745,00 euros in France and in UK 685pounds) [14].Given the exogenous nature of terrorism as a hardly predictable risk, the issue of its control is the public authorities prerogative.

\section{Culture as a strategic risk-factor}

In the fashion industry, market entry strategy always involves finding local partners and rigorous competitor's analysis, as local brands have a much better understanding of the tastes, interests, trends, and physical silhouettes features. Therefore, for foreign companies wishful to capture a new market, it is always a massive challenge. 
For many mass media, realizing the function of stimulating foreign brands sales through colorful media campaign, the work on the regional market is also full of complications. Executive Director of the media group Condé Nast India Kurivilla Alex said that since the launch of Vogue and GQ magazines in India, they aim to capture a fascinating variety and miscellaneous tastes of Indian consumers. Editorial coverage must neatly balance many elements - old and new money, youth and maturity, tradition and modernity, Western and Indian styles, national and regional level, high fashion and street style [15]. Despite the fact that the media group Condé Nast publications talk about world manifold catwalks, however, the article trends reports must be understood by local auditoria - Indian woman or a man. Therefore, it is adjusted tactics to produce locally the editorial material as to meet successfully interests multiplicity. Foreign brands that seek advertising campaigns to authoritative media sources often require creating specific promotional campaign using local persons. Models with the nationality of the emerging markets are becoming nowadays that new significant communication element that firmly links foreign brand and its local audience. Indian model Lakshmi Menon coruscated at the Paris Fashion Week runways, at the same time when Christian Dior and many other western luxury segment brands for the first time went to India with a wave of retail investment and high hopes that the country will become a new engine in the fashion industry growth [15]. The Russian fashion industry market is estimated by many analytical agencies as one of the most promising for foreign brands expansion. Despite the macroeconomic fluctuations of the national currency, for tourist's circumstances are best - favorable exchange rates is economically successful occasion for the inbound tourism shopping development. Retailers in the Russian fashion industry, which fruitfully react to this (TSUM, DLT), now implement brand new programs to create a comfortable tourists environment. China friendly program is a superior example, tracked at the Russian shopping tourist product promotion on the international market. The Chinese POS materials translation is a big stride toward attracting new customers and increasing fashion and tourism both industries revenues. This is a crucial example of that fashion-strategists [16] are able to receive an external impulse, readily and rapidly analyze it and react to it in a strategic decision-making process [17].Another great example of successful cultural investments risk management is the clothing youth brand creation in Russia -KiraPlastinina brand. I could define following strong competitive advantages - the designer belonging to the age group of consumers (clothing product is designed for young women aged 15-25 years by the brand creative author and designer 18 year old KiraPlastinina itself), the author's private part of the designer in developing the collections, as well as commercial value for money. As the brand has taken into account Russian youth needs and interests of low-cost designer clothing it caused a positive revolution on market by calibrated tactics - once cloth with KiraPlastinina's logo can be seen one very second schoolgirl, glamorous socialite Paris Hilton came to present new collection in Moscow, vibrant advertisement campaigns with star youth featured serials, sightly stores opened in Armenia, Belarus, Kazakhstan, Kyrgyzstan, Moldova and Ukraine [18].However, the same brand ignored cultural risk-factor during entry USA strategy development in 2008. Was there any sense to enter new specific market, not having properly studied the mentality, as an example, teen's reluctance to spend money on «designer» clothes at all? USA teenagers prefer to spend their money more on the American massmarket clothes, electronic devices, entertainment (video games) and food [19]. In this regard, the KiraPlastininabrand development strategy in USA had failed - in the US in 2008 it was opened12 stores initially, and then the total number has been reduced to 2 .

\section{Conclusion}

Risks that exist in emerging market are very often arduous to predict, and almost no insurable. However, fashionstrategists should be able to anticipate them in order to minimize damage and to develop an optimal investment strategy. Political risks and terrorism are exogenous risk factors. The strategic decisions adoption and implementation processes aimed to reduce the unfavorable result probability onset from risks exposure is extremely complex. It is worth noting that the key success factors in emerging markets are the localization and adaptation. 


\section{References}

Ernst \& Young. Official Page. Cultural times. The first global map of cultural and creative industries. URL: http://www.ey.com/Publication/vwLUAssets/eycultural-times-2015/\$FILE/ey-cultural-times-2015.pdf p. 15. (25.01.2017)

Integreon. Official Page. The global fashion industry - growth in emergingmarkets. URL: http://www.integreon.com/BlogDetails?BGID=260 (23.01.2017)

Kvint V. Strategy for the Global Market. Theory and Practical Applications. Routledge Taylor \& Francis Group. 2016 - P. 436-437

see [3]. - P. 120-156

The term by author Khvorostyanaya A.S. Khvorostyanaya A.S. Kuznecova K.V. The theoretical foundation of fashion industry strategizing. Russian Scientific Journal of Economics and Management №4 (126) 2016, p. 33. - on

Russian

The Indian Express. Official Page. Rs 500 and 1000 currency demonetized: PM Modi URL: http://indianexpress.com/article/business/economy/narendra-modi-500-100-indian-rupee-notesdemonetised-4364660/ (20.01.2017)

Whatsapp. Official Page. URL: https://www.whatsapp.com (20.01.2017)

Fernandez C. What India's Currency Crackdown Means For Fashion

URL:https://www.businessoffashion.com/articles/global-currents/what-indias-currencycrackdown-meansforfashion?utm_source=Subscribers\&utm_campaign=500e64224b\&utm_medium=email\&utm_term=0_d2191372b3-500e64224b-417343273(29.12.2016)

see [3]. - P. 75-112

Popova N. Key facts - How much money Fashion Week brings to Paris - onRussian (Попова Н. Ключевыефакты-СколькоденегприноситПарижуНеделямоды) URL: https://fashionunited.ru/novostee/beeznyes/klyuchevyefakty-skolko-deneg-prinosit-parizhu-nedelyamody/2016092716245 (21.01.2017)

RFI. Official Page. Where is «Bataklan»?: What happened to tourism after theterrorist attacks in Paris - on Russian (Гдетут «Батаклан»?:чтостало стуризмом в Парижепослетерактов) URL: http://ru.rfi.fr/frantsiya/20161112-gde-tut-bataklan-chto-stalo-s-turizmom-v-parizhe-posle-teraktov (13.11.2016)

LVMH. Official Page. Report. URL:https://www.lvmh.ru/shareholders/agenda/2015-full-year-results/ (17.11.2016)

Wojtowicz A. Is Paris remains the world capital of fashion since last year'sterrorist attacks? - on Russian (ОсталсялиПарижмировойстолицеймодыпослепрошлогоднихтерактов?) URL: http://ru.rfi.fr/frantsiya/20160125-nedelya-muzhskoi-mody-ostalsya-li-parizh-mirovoi-stolitsei-modyposleproshlogodn(30.11.2016)

LVMH. Official Page. Louis Vuitton. https://www.lvmh.fr/les-maisons/modemaroquinerie/louis-vuitton/ (14.11.2016)

Young R. Is India the Solution to Fashion's Woes? URL:https://www.businessoffashion.com/articles/globalcurrents/india-rising-globalfuture-fashion-industry (14.11.2016)

see $[5]-$ P. 37

SSF. Official Page. How to arrange: FASHION-STRATEGIST ANNAKHVOROSTYANAYA - on Russian URL:

http://so-serious.ru/kak-ustroenofashion-strateg-anna-xvorostyanaya/ (20.01.2017)

Retail.Ru Official Page. KiraPlastinina has not become profitable - on Russian URL: https://www.retail.ru/news/128120/ (20.01.2017)

Business Insider. Official Page. Here's How Teens Really Spend Money, What They Like, And Where They Shop. URL:http://www.businessinsider.com/how-teens-are-spending-money-2014-2014-10(19.01.2017) 